\title{
Prevalence and risk factors of postpartum dyspareunia at three months post- delivery in Sudanese women
}

\author{
Inas Mohamed Elhassan Abd. Alkareem¹, Mohamed Ahmed A/Gadir Elimam Ounsa², \\ Elsadig Yousif Mohamed ${ }^{3 *}$, Elsadig Mohamed ${ }^{3}$, Sawsan Abdalla ${ }^{3}$
}

\begin{abstract}
${ }^{1}$ Department of Obstetrics and Gynecology, Khartoum teaching hospital, Khartoum, Sudan
${ }^{2}$ Department of Obstetrics and Gynecology, Faculty of Medicine, The National Ribat University, Khartoum, Sudan

${ }^{3}$ Department of Community Medicine, College of Medicine, Majmaah University, Saudi Arabia
\end{abstract}

Received: 14 May 2017

Accepted: 10 June 2017

\section{*Correspondence: \\ Dr. Elsadig Yousif Mohamed, \\ E-mail: elsadigoo@gmail.com}

Copyright: (c) the author(s), publisher and licensee Medip Academy. This is an open-access article distributed under the terms of the Creative Commons Attribution Non-Commercial License, which permits unrestricted non-commercial use, distribution, and reproduction in any medium, provided the original work is properly cited.

\section{ABSTRACT}

Background: Postpartum dyspareunia affects many women following childbirth: however, the extent of the problem is difficult to estimate. The objectives of the current study were to determine the prevalence of postpartum dyspareunia and to estimate its risk factors.

Methods: This is a cross-sectional study conducted at the National Ribat University Hospital, Sudan. The study was carried out on women attended the refer clinics of obstetrics and gynecology and pediatrics departments in the hospital. The sample size was calculated as 380. The data were collected by a pre-tested questionnaire along with a clinical examination of the vulva and vagina after obtaining the ethical approval. The SPSS was used to analyze the data.

Results: The prevalence of postpartum dyspareunia in women attended the National Ribat University hospital was $42.6 \%$. Regarding age, $8(61.5 \%)$ of women less than 20 years of age experienced dyspareunia, $102(46.4 \%)$ and 52 $(35.4 \%)$ of women whose age was 20-29 years; and more than 29 years experienced the condition. One hundred forty $(51.7 \%)$ of women who delivered by normal vaginal delivery developed postpartum dyspareunia. Eight $(72.7 \%), 8$ $(12.5 \%)$ and $6(17.6 \%)$ of women delivered by Operative vaginal, Elective C/S and Emergency C/S developed postpartum dyspareunia respectively. One hundred forty-eight (62.4\%), 153 (51.3\%) women who had decircumcision and episiotomy in last delivery had postpartum dyspareunia respectively. Forty-six (93.3\%), fifty-three (86.9\%) and $60(87 \%)$ women who had infected episiotomy, scar tissue at episiotomy and tight interoitus developed the condition respectively.

Conclusions: The prevalence of postpartum dyspareunia in women attended the National Ribat University hospital was $42.6 \%$. Regarding age, $8(61.5 \%)$ of women less than 20 years of age experienced dyspareunia, $102(46.4 \%)$ and $52(35.4 \%)$ of women whose age was 20-29 years; and more than 29 years experienced the condition. One hundred forty $(51.7 \%)$ of women who delivered by normal vaginal delivery developed postpartum dyspareunia. Eight (72.7\%), $8(12.5 \%)$ and $6(17.6 \%)$ of women delivered by Operative vaginal, Elective C/S and Emergency C/S developed postpartum dyspareunia respectively. One hundred forty-eight (62.4\%), $153(51.3 \%)$ women who had decircumcision and episiotomy in last delivery had postpartum dyspareunia respectively. Forty-six (93.3\%), fifty-three (86.9\%) and $60(87 \%)$ women who had infected episiotomy, scar tissue at episiotomy and tight interoitus developed the condition respectively.

Keywords: Prevalence, Postpartum dyspareunia, Risk factors 


\section{INTRODUCTION}

Dyspareunia is defined as: Any pain or soreness that occurs during sexual intercourse. Dyspareunia following childbirth can be physical, psychological or both. ${ }^{1}$ According to the World Health Organization (WHO), a healthy sexuality can't be merely defined as the absence of sexual dysfunction, but as a state of physical, mental and social wellbeing related to sexuality. This sexual function is a fundamental part of each human being personality and a cornerstone in the overall couple relationship. ${ }^{2}$ Episiotomy is an important risk factor for short term postpartum female sexual dysfunction (PPFSD). ${ }^{3}$

Complications of episiotomy such as infection, episiorrhaphy dehiscence and constricted introitus have a strong role in developing dyspareunia. Postpartum dyspareunia affects many women following childbirth: however, the extent of the problem is difficult to estimate. ${ }^{1,4}$ Sexuality has normal fluctuation during different phases of life, in which child birth is one such phase. It can bring many changes that may alter women's sexual needs and affect partners' relationship. ${ }^{5}$ In a study conducted in Sharkia Governorate in Egypt, proximately $16 \%$ of circumcised women complained of dyspareunia and believed that it was related to circumcision6. In Eastern Sudan, the prevalence of dyspareunia was $48.0 \% .^{7}$ In Sudan postpartum dyspareunia is a common problem with a great social impact, but still women find it difficult to explore to their physician. The common mode of delivery in the country is vaginal with episiotomy, decircumcision and re-infibulation; these are in general associated with dyspareunia. Female Genital Mutilation and cutting (FGM/C), which is widely practices in Sudan, is associated with dyspareunia. ${ }^{8}$ Dyspareunia is to some extent an avoidable and treatable condition; its identification may lead to prevention and early treatment. Data regarding dyspareunia is scanty in the Sudan.

The objectives of the current study were to determine the prevalence rate of postpartum dyspareunia at three months Post-delivery, its relationship with social factors and to estimate the risk factors of the condition.

\section{METHODS}

This is a cross-sectional and hospital-based study conducted at the National Ribat University Hospital, Khartoum, Sudan. The study was carried out on women attended the refer clinics of obstetrics and gynecology and pediatrics departments in the hospital. Women who delivered within three months and resume sexual intercourse after delivery were included in the study.

The sample size was calculated by the formula $\mathrm{n}=\mathrm{t} 2 \times \mathrm{p}(1-\mathrm{p}) / \mathrm{m}^{2}$ where, $\mathrm{n}=$ sample size, $\mathrm{t}=$ confidence level at $95 \%$ (standard value of 1.96), $\mathrm{p}=$ estimated prevalence of 3 months postpartum dyspareunia $=45 \%, \mathrm{~m}=$ margin of error at $5 \%$ (standard value of 0.05 ). The sample size was calculated as 380 .The data were collected by a pre-tested questionnaire along with a clinical examination of the vulva and vagina.

\section{Statistical analysis}

The SPSS for Windows software version 21 (SPSS, Chicago, Illinois, USA) was utilized to analyze the data. Descriptive statistics was used (frequency and standard deviation). The chi-squared test was used to compare the qualitative data. $\mathrm{P}$ value less than 0.05 was considered significant and all tests were 2 -sided.

\section{RESULTS}

According to these results, the prevalence of postpartum dyspareunia in women attended the Ribat University hospital was $42.6 \%$ (162/380). Regarding age, 8 (61.5\%) of women less than 20 years of age experienced dyspareunia, $102(46.4 \%)$ and $52(35.4 \%)$ of women whose age was 20-29 years; and more than 29 years experienced the condition; the relation between age of women and developing postpartum dyspareunia is significant $(\mathrm{p}=0.001)$. Five $(29.4 \%)$ and $126(44.5 \%)$ of illiterate women and those who acquired General education developed postpartum dyspareunia. Thirty-one (38.7\%) of women who had University and above education developed the disease.

Table 1: Relation between postpartum dyspareunia and social factors $(n=380)$.

\begin{tabular}{|c|c|c|c|c|}
\hline \multirow{2}{*}{$\begin{array}{l}\text { Social } \\
\text { factor }\end{array}$} & \multicolumn{2}{|c|}{$\begin{array}{l}\text { Postpartum } \\
\text { dyspareunia }\end{array}$} & \multirow[t]{2}{*}{ Total } & \multirow[t]{2}{*}{ p } \\
\hline & Yes $(\%)$ & No $(\%)$ & & \\
\hline \multicolumn{5}{|c|}{ Age (years) } \\
\hline $\begin{array}{l}\text { Less than } \\
20\end{array}$ & $\begin{array}{l}8 \\
(61.5 \%)\end{array}$ & $5(38.5 \%)$ & 13 & \multirow{4}{*}{0.001} \\
\hline $20-29$ & $\begin{array}{l}102 \\
(46.4 \%)\end{array}$ & $\begin{array}{l}118 \\
(53.6 \%)\end{array}$ & 220 & \\
\hline $\begin{array}{l}\text { More than } \\
29\end{array}$ & $\begin{array}{l}52 \\
(35.4 \%)\end{array}$ & $\begin{array}{l}95 \\
(64.6 \%)\end{array}$ & 147 & \\
\hline Total & $\begin{array}{l}162 \\
(42.6 \%)\end{array}$ & $\begin{array}{l}218 \\
(57.4 \%)\end{array}$ & 380 & \\
\hline \multicolumn{5}{|c|}{ Level of education } \\
\hline Illiterate & $\begin{array}{l}5 \\
(29.4 \%)\end{array}$ & $\begin{array}{l}157 \\
(55.5 \%)\end{array}$ & 17 & \multirow{4}{*}{0.084} \\
\hline $\begin{array}{l}\text { General } \\
\text { education }\end{array}$ & $\begin{array}{l}126 \\
(44.5 \%)\end{array}$ & $\begin{array}{l}49 \\
(61.3 \%)\end{array}$ & 283 & \\
\hline $\begin{array}{l}\text { University } \\
\text { and above }\end{array}$ & $\begin{array}{l}31 \\
(38.7 \%)\end{array}$ & $\begin{array}{l}218 \\
(57.4 \%)\end{array}$ & 80 & \\
\hline Total & $\begin{array}{l}162 \\
(42.6 \%)\end{array}$ & & 380 & \\
\hline
\end{tabular}


The relation between level of education and postpartum dyspareunia is not significant $(\mathrm{p}=0.084)$ as shown in Table 1.

Table 2 shows the relation between postpartum dyspareunia and last delivery. Eighteen (39.1\%) women who had history of postpartum dyspareunia developed the condition, while $144(43.1 \%)$ women who had no history developed the disease; the relation between history of postpartum dyspareunia and developing the condition in the subsequent postpartum period is not significant $(\mathrm{p}=0.609)$. One hundred forty $(51.7 \%)$ of women who delivered by normal vaginal delivery developed postpartum dyspareunia. Eight (72.7\%), 8 (12.5\%) and 6 (17.6\%) of women delivered by Operative vaginal, Elective $\mathrm{C} / \mathrm{S}$ and Emergency $\mathrm{C} / \mathrm{S}$ developed postpartum dyspareunia respectively.

Table 2: Relation between postpartum dyspareunia and last delivery.

\begin{tabular}{|llll|}
\hline \multirow{2}{*}{ Item } & Postpartum dyspareunia & & Total \\
\cline { 2 - 3 } & Yes $(\%)$ & No $(\%)$ & \\
\hline History of previous dyspareunia & & & $46(12.1 \%)$ \\
\hline Yes & $18(39.1 \%)$ & $28(60.9 \%)$ & $334(87.9 \%)$ \\
\hline No & $144(43.1 \%)$ & $190(56.9 \%$ & $380(100 \%)$ \\
\hline Total & $162(42.6 \%)$ & $218(57.4 \%)$ & \\
\hline Mode of last delivery & & & $271(71.3 \%)$ \\
\hline Normal vaginal & $140(51.7 \%$ & $131(48.3 \%)$ & $11(2.9 \%$ \\
\hline Operative vaginal & $8(72.7 \%$ & $3(27.3 \%)$ & $64(16.8 \%)$ \\
\hline Elective C/S & $8(12.5 \%$ & $56(87.5 \%)$ & $34(9.0 \%)$ \\
\hline Emergency C/S & $6(17.6 \%)$ & $28(82.4 \%)$ & $380(100 \%)$ \\
\hline Total & $162(42.6 \%)$ & $218(57.4 \%)$ & \\
\hline
\end{tabular}

Table 3: Risk factors of postpartum dyspareunia.

\begin{tabular}{|llll|}
\hline \multicolumn{2}{c}{ Item } & Postpartum dyspareunia & Total \\
\cline { 2 - 4 } Decircumcision in last delivery & & No $(\%)$ & \\
\hline Yes & $148(62.4 \%)$ & $105(37.6 \%$ & $237(84.0 \%)$ \\
\hline No & $16(35.6 \%)$ & $29(64.4 \%)$ & $45(16.0 \%)$ \\
\hline Total & $148(52.5 \%)$ & $134(47.5 \%)$ & $282(100.0 \%)$ \\
\hline Episiotomy in the last delivery & & & $261(92.6 \%)$ \\
\hline Yes & $143(51.3 \%)$ & $118(48.7 \%)$ & $21(7.4 \%)$ \\
\hline No & $5(23.8 \%)$ & $16(76.2 \%)$ & $282(100 \%)$ \\
\hline Total & $148(52.5 \%)$ & $134(47.5 \%)$ & $49(17.4 \%)$ \\
\hline History of infected episiotomy & & & $233(82.6 \%)$ \\
\hline Yes & $46(93.9 \%)$ & $3(6.1 \%)$ & $282(100 \%)$ \\
\hline No & $102(43.8 \%)$ & $131(56.2 \%)$ & \\
\hline Total & $148(52.5 \%)$ & $134(47.5 \%)$ & $61(21.6 \%)$ \\
\hline Scar tissue at episiotomy site & & & $221(78.4 \%)$ \\
\hline Yes & $53(86.9 \%)$ & $8(13.1 \%)$ & $282(100 \%)$ \\
\hline No & $95(43.0 \%)$ & $126(57.0 \%)$ & \\
\hline Total & $148(52.5 \%)$ & $134(47.5 \%)$ & $69(24.5 \%)$ \\
\hline Tight interoitus & & & $213(75.5 \%)$ \\
\hline Yes & $60(87 \%)$ & $125(58.7 \%)$ & $282(100 \%)$ \\
\hline No & $88(41.3 \%)$ & $134(47.5 \%)$ & $9(13 \%)$ \\
\hline Total & $148(52.5 \%)$ & & \\
\hline
\end{tabular}

Table 3 shows the risk factors of postpartum dyspareunia. Results shows that $148(62.4 \%)$ women who had decircumcision in last delivery had postpartum dyspareunia compared to $16(35.6 \%)$ who did not have decircumcision in last delivery; the relation between postpartum dyspareunia and decircumcision in last delivery is significant $(\mathrm{p}=0.013)$. One hundred forty-three $(51.3 \%)$ women who had episiotomy in the last delivery 
developed postpartum dyspareunia while 5 (23.8\%) who haven't undergone episiotomy in the last delivery developed the condition; the relation between postpartum dyspareunia and episiotomy in last delivery is significant $(\mathrm{p}=0.006)$.

Forty-six (93.9\%) women who developed postpartum dyspareunia had a history of infected episiotomy while 102 (43.8\%) who didn't have infected episiotomy developed the condition; the relation between postpartum dyspareunia and History of infected episiotomy is significant $(<0.001)$. Fifty-three $(86.9 \%)$ women who had postpartum dyspareunia had a scar tissue at episiotomy site. On the other hand, $95(43.0 \%)$ of women who haven't scar tissue at episiotomy site developed postpartum dyspareunia; the relation between postpartum dyspareunia and presence of scar tissue at episiotomy site is significant $(<0.001)$. Sixty $(87 \%)$ women who had tight interoitus developed postpartum dyspareunia compared to $88(41.3 \%)$ who didn't have tight interoitus developed the disease; the relation between postpartum dyspareunia and presence of tight interoitus is significant $(\mathrm{p}<0.001)$.

\section{DISCUSSION}

The aim of the current study was to estimate the prevalence rate of postpartum dyspareunia in Sudanese women. It is very difficult to exactly determine the prevalence of postpartum dyspareunia since many patients especially in our communities don't disclose their problem and hence seek medical attention due to sociocultural barriers. ${ }^{9}$ The results showed that $42.6 \%$ of women developed the condition. This result seems to be higher than the prevalence of $9.5 \%, 14.5 \%$ and $9.3 \%$ reported by KR Mitchell, Boran SA et al and Danielson I et al. ${ }^{10-12}$

Postpartum dyspareunia is most prevalent among younger women less than twenty years of age, this is consistent with Danielson I, et al who also found the incidence risk ratio of 9.3 between the younger and older age groups. Our results showed no significant difference of the previous dyspareunia and the development of the postpartum dyspareunia. It was reported by Barrett $G$ et al that dyspareunia in the first three months after delivery was significantly associated with previous experience of the condition. ${ }^{13}$ The findings of the study showed an increase rate of postpartum dyspareunia among women delivered by operative vaginal delivery followed by normal vaginal delivery. The relation between mode of delivery and postpartum dyspareunia, according to our study, is significant $(\mathrm{p}<0.001)$. This finding is in line with Barrett $G$ et al, however: Dabiri $F$ et al, showed no significant association between mode of delivery and postpartum dyspareunia. ${ }^{13,14}$

Postpartum dyspareunia is significantly associated with Decircumcision, episiotomy, infection, scar tissue formation at episiotomy site and tight interoitus. ${ }^{3,15,16}$.
This is consistent with Boran SA who stated that episiotomy is associated with dyspareunia. ${ }^{11}$ It is suggested that women who underwent an episiotomy during delivery experienced delayed sexual activity and had severe dyspareunia at 3 months postpartum. ${ }^{17}$ The study findings showed that there is a significant association between postpartum dyspareunia, infected episiotomy and presence of scar at its site along with tight interoitus. These finding are consistent with SolanaArellano E et al. ${ }^{18}$

\section{CONCLUSION}

The study concluded that the prevalence of dyspareunia in Sudanese women is high. The disease is reduced as age increases. The prevalence of dyspareunia, which is high in women who delivered by normal vaginal delivery, is statistically associated with the mode of delivery; the risk factors of dyspareunia are decircumcision, presence and history of infected episiotomy, scar tissue at episiotomy site and tight interoitus.

\section{Funding: No funding sources}

Conflict of interest: None declared

Ethical approval: The study was approved by the Institutional Ethics Committee

\section{REFERENCES}

1. Heli LJ. Evaluation and differential diagnosis of dysparunia. Am Fam Physician. 2001;63(8):1535-44.

2. Serati M. Female sexual function during pregnancy and after childbirth. J Sex Med. 2010;7:2782-90.

3. Sayasneh A. Postpartum functional dysfunction: A literature review of risk factors and role of mode of delivery. British J Med Pract. 2010;3(2):316-20.

4. Goetsch FM. Postpartum Dyspareunia an unexpected problem. J Reprod Med. 1999;44(11):963-8.

5. Rathfisch G, Dikencik BK, Beji NK. Effect of perineal trauma on postpartum sexual function; $\mathbf{J}$ Advanced Nursing. 2010; 66(12): 2640-9.

6. Arafa EM, Abdelghany AM, Madkour NM, Nossair WS, Mohamed EA. Survey Study of Acute and Long Term Effects of Female Genital Mutilation among Women in Sharkia Governorate. Open Journal of Obstetrics and Gynecology. 2014 Sep 29;4(14):874.

7. Ali AA1, Abdallah TM. Clinical presentation and epidemiology of female genital tuberculosis in eastern Sudan. Int J Gynecol Obstet. 2012;118(3):236-8.

8. Berg RC, Underland V, Odgaard-Jensen J, Fretheim A, Vist GE. Effects of female genital cutting on physical health outcomes: a systematic review and meta-analysis. BMJ open. 2014;4(11):e006316.

9. Kettle C, Ismail $\mathrm{K}$ and O'Mahony F. Dyspareunia following childbirth. Obstet Gynecol. 2005;7:245-9.

10. Mitchell KR, Geary R, Graham CA, Datta J, Wellings K, Sonnenberg $P$ et al. Painful sex (dyspareunia) in women: prevalence and associated 
factors in a British population probability survey. BJOG: International J Obstet Gynecol. 2016:1-9.

11. Boran SA, Cengiz H, Erman O, Erkaya SS. Episiotomy and the development of postpartum dyspareunia and anal incontinence in nulliparous females. Eurasian J Med. 2013;45(3):176-80.

12. Danielsson I, Sjoberg I, Stenlund H, Wikman M. Prevalence and incidence of prolonged and severe dyspareunia in women: results from a population study. Scandinavian J Public Health. 2003;31(2). Available http://journals.sagepub.com/doi/abs/10.1080/140349 40210134040

13. Barrett G, Pendry E, Peacock J, Victor C, Thakar R, Manyonda I. Women's sexual health after childbirth. BJOG: Int J Obstet Gynecol. 2000;107(2):186-95.

14. Dabiri F, Yabandeh AP, Shahi A, Kamjoo A, Teshnizi SH. The Effect of Mode of Delivery on Postpartum Sexual Functioning in Primiparous Women. Oman Med J. 2014;29(4):276-9.

15. Safarinejad M, Kolahi A, Hosseini L. The effect of the mode of delivery on the quality of life, sexual function and sexual satisfaction in Primiparous women and their husbands. J Sex Med. 2009;6:164567.

16. Nour NM. Defibrillation to treat female genital cutting: effect on symptoms and sexual function. $\mathbf{J}$ Obstet Gynecol. 2006;108:55-60.

17. Sartore A, De Seta F, Mso G, Pregazzi R, Grimaldi E, Guaschino S. The effects of mediolateral episiotomy on pelvic floor function after vaginal delivery. Obstet Gynecol. 2004;103:669-73.

18. Solana-Arellano E, Villegas-Arrizón A, LegorretaSoberanis J, Cárdenas-Turanzas M, Enzaldo de la Cruz J, Andersson N. Women's dyspareunia after childbirth: a case study in a hospital in Acapulco, Mexico. Rev Panam Salud Publica. 2008;23(1):4451.

Cite this article as: Abd. Alkareem IME, Mohamed Ounsa AAGE, Mohamed EY, Abdalla S. Prevalence and risk factors of postpartum dyspareunia at three months post- delivery in Sudanese women. Int $\mathrm{J}$ Reprod Contracept Obstet Gynecol 2017;6:2716-28. 